原著

\title{
低濃度フッ化物溶液（F：100 ppm）洗口
}

\section{によるう蝕抑制効果}

一一第 1 褺：臨地試験結果 ${ }^{*}-$

\author{
荒川浩 久**
}

\begin{abstract}
懒要：フッ化物の局所応用法のうち, 自律的応用として分類されているフッ化物洗口法は, 公乘衛生特 性に優れたう蚛予防手段として広く応用されているが，洗口液のフッ来湌度をはしめとする洗口条件は， いまだに不統一であるところが多い。特に，現在主流をなしている洗口液のフッ秦浊度が決定された根 拠は，そう明礁なものとはいいがたいようである。そこで，従来のものに比べかなり低濃度化した0.023 \%弱酸性（pH 5.0） NaF 溶液（100 ppmF）による週 5 回の洗口を実施し，果して十分なう触抑制効果 があるものかどうかについて検封してみた。

対象は，同一地城内にある $2 つ$ 小学校に在学する児童であり，一校を洗口校，他校を対照校として， フッ化物洗口以外は全く同様な齿科管理を行った。洗口の教果は, 入学時点から卒莱するまで本研究に 継繶的に参加した洗口校79名，非洗口校63名の口腔内診査結果をもとに，6年間のう蚛の変動を中心に， 前むき的に険封した。

6 年後の洗口校児童のう蝕抑制率は，DMFT 指数で $52.2 \%$, DMFS 指数で $51 \%$ と有意なものであっ た。またさらに，種々な分析を試みたが，そのいずれにおいても十分な効果が示された。以上のことよ り，フッ素として $100 \mathrm{ppm}$ という低湦度のフッ化物洗口は, 学校齿科保健管理上, 極めて有勃かつ安全 なう触予防手段となり得ることが明らかとなった。
\end{abstract}

索引用語 : 低溃度フッ来, 洗口, う蚛抑制

はじめに

先進諸外国では，地域の歯科保健プログラムとして， 地域飲料水中のフッ素（以下F と略記）を至適䈨度にコ ントロールしているところが数多く見られる゙のに対 し，わが国では，現在のところ全身的なF応用がなされ ている地域はなく2)，公衆衛生特性に位れた応用は極め て希薄である。しかし，F局所応用法のなかで最も公衆 衛生特性に優れている2,3) フッ化物溶液洗口（以下F洗 口と略記）が, 近年, 幼稚園や小学校を中心に普及しつ つあり，推計で11万人もの子供たちが集団的に応用して
いるといわれている。

このF洗口の歴史は古く, 40年ほど前の Bibby)にま でさかのぼらなければならないが，今日まで種々な検郡 と改良がなされており, 费用, マンパワー, 予防効果, 手技の容易さ，安全性などいずれの面からみても，偡れ たう強予防手段として，集団のう蝕予防管理に広く応用 されているものである。しかし，Bibby から今日までの F 洗口に関する業績(5-15)を振り返ってみると，洗口液の フッ化物の種類, $\mathrm{pH}, \mathrm{F}$ 筡度および液量, 時間, 応用 頿度などの洗口条件については，いまだ確立されたもの とはいいがたいところがある。わが国においては，可児

* 本研究の要旨は第32回日本口腔衙生学会（昭和58年10月）において発表した。

** 神奈川歯科大学口腔衛生学教室（主任：饭塚喜一教投）

* Department of Dental Health \& Public Health, Kanagawa Dental College, Yokosuka, Japan (Director : Prof. Yoshikazu IIZUKA)

昭和 59 年 8 月 22 日受付 
Table 1 Examples of fluoride mouth-rinsing in Japan

\begin{tabular}{|c|c|c|c|c|c|c|c|c|c|c|c|c|}
\hline \multirow[b]{2}{*}{ reference } & \multirow[b]{2}{*}{$\begin{array}{l}\text { fluo- } \\
\text { ride }\end{array}$} & \multirow{2}{*}{$\begin{array}{l}\text { concen- } \\
\text { tration } \\
(\mathrm{ppm} F)\end{array}$} & \multicolumn{3}{|c|}{ ring1ng method } & \multirow[b]{2}{*}{ period } & \multicolumn{2}{|c|}{ materials } & \multicolumn{4}{|c|}{ carles reduction $(\%)$} \\
\hline & & & \begin{tabular}{|c|}
$\begin{array}{c}\text { volume of } \\
\text { solution } \\
\text { (m1) }\end{array}$ \\
\end{tabular} & $\begin{array}{l}\text { rinsing } \\
\text { time } \\
\text { (sec.) }\end{array}$ & $\begin{array}{l}\text { frequen- } \\
\text { cy }\end{array}$ & & age & number & DMFT & $\begin{array}{c}\text { DMFT } \\
\text { rate }\end{array}$ & DMFS & $\begin{array}{l}\text { DMFS } \\
\text { rate }\end{array}$ \\
\hline $\begin{array}{r}\text { T. Kasakura } \\
(1966)\end{array}$ & $\mathrm{NaF}$ & 450 & 5 & 10 & da1ly & $1-2$ & $9-11$ & 41 & $\begin{array}{c}60 \\
(2 \text { year } 8)\end{array}$ & $\begin{array}{c}92 \\
(2 \text { years })\end{array}$ & - & - \\
\hline $\begin{array}{r}\text { M. Kan1, et al.7) } \\
\text { (1973) }\end{array}$ & $\begin{array}{l}\mathrm{NaF} \\
\text { pH5.0 }\end{array}$ & 500 & 10 & 30 & dally & 3 & 10 & 99 & 29 & 一 & 32 & 一 \\
\hline \multirow{4}{*}{$\begin{array}{c}\text { Y. Shimada, } \\
\text { et al. }{ }^{24)} \\
\text { (1975) }\end{array}$} & \multirow{4}{*}{$\mathrm{NaF}$} & \multirow{4}{*}{450} & \multirow{4}{*}{$7-9$} & \multirow{4}{*}{30} & \multirow[t]{2}{*}{ monthly } & \multirow[t]{2}{*}{4} & \multirow[t]{2}{*}{$6-12$} & \begin{tabular}{|l|l} 
m. & 880 \\
\end{tabular} & 13 & 7 & \multirow[t]{2}{*}{-} & \multirow[t]{2}{*}{ - } \\
\hline & & & & & & & & f. 977 & 4 & 3 & & \\
\hline & & & & & \multirow{2}{*}{ weekly } & \multirow{2}{*}{3} & \multirow{2}{*}{$6-12$} & m. 773 & 28 & 22 & \multirow{2}{*}{ - } & \multirow{2}{*}{ - } \\
\hline & & & & & & & & f. 731 & 20 & 18 & & \\
\hline \multirow{2}{*}{$\begin{array}{c}\text { Y.Shimada, } \\
\text { et al. } \\
\text { (1978) }\end{array}$} & \multirow{2}{*}{$\mathrm{NaF}$} & 45 & 10 & 30 & \multirow{2}{*}{ daxly } & \multirow{2}{*}{2} & \multirow{2}{*}{$6-10$} & 56 & $32^{\circ}$ & 32 & 29 & 31 \\
\hline & & 225 & $7-10$ & 30 & & & & 195 & 38 & 33 & 27 & 19 \\
\hline $\begin{array}{c}\text { O. Saka1, et } \\
\text { al. 21) } \\
\text { (1973) }\end{array}$ & $\mathrm{NaF}$ & 900 & 10 & 60 & weekly & 3 & $6-9$ & 392 & 一 & - & $60-70$ & - \\
\hline $\begin{array}{c}\text { S. Kobayash1, } 26) \\
\text { et al. } \\
(1978)\end{array}$ & $\mathrm{NaF}$ & 225 & 7 & 60 & dally & 4 & $\begin{array}{c}4-8 \\
(4-11)\end{array}$ & $\begin{array}{c}51 \\
(498)\end{array}$ & $\begin{array}{c}79 \\
(19-79)\end{array}$ & - & - & - \\
\hline $\begin{array}{r}\text { E. Kitsugi }^{27)} \\
(1978)\end{array}$ & $\mathrm{NaF}$ & 225 & $5-10$ & 60 & dally & 6 & $\begin{array}{c}6-12 \\
(6-9)\end{array}$ & $\begin{array}{c}77 \\
(242)\end{array}$ & $\begin{array}{c}63 \\
(36-67)\end{array}$ & & 一 & - \\
\hline
\end{tabular}

Table 2 Medical and dental facilities in the experimental area

\begin{tabular}{c|c|c|c|c|c}
\hline the year & $\begin{array}{l}\text { number of } \\
\text { hospitals }\end{array}$ & $\begin{array}{l}\text { number of } \\
\text { medical } \\
\text { clinics }\end{array}$ & $\begin{array}{l}\text { number of } \\
\text { physicians }\end{array}$ & $\begin{array}{l}\text { number of } \\
\text { dental } \\
\text { clinics }\end{array}$ & $\begin{array}{l}\text { number of } \\
\text { dentists }\end{array}$ \\
\hline 1977 & 2 & 22 & 34 & 8 & 10 \\
1982 & 2 & 28 & 33 & 9 & 14 \\
\hline
\end{tabular}

$ら^{16-20)}$ によるF として $500 \mathrm{ppm}, \mathrm{pH} 5.0$ の洗口液にて30 秒間，毎日洗口する方法と，境ら ${ }^{21) に よ る F ~ と し て ~} 900$ ppm の洗口液にて 1 分間, 週 1 回洗口する方法が中心 に応用されているようである22-28) (Table 1 参照)。Table 1 を見ると，う蝕抑制率の算出方法 対象作㱓, 研 究期間さらに地域特性などが異なるためか, 予防勃果は 20 60\%とばらついている。しかし洗口液のF浱度や洗 口条件などに関しては, 確固たる根拠もなく不統一であ ることがわかる。

このような情況ではあるが，洗口時間や液量よりも， F が齿面に接触する頻度, つまり洗口頻度の多い方に高 い効果があらわれるという報告が多い6,7,9,15,28,24)。また 洗口液の F 笯度の差については, 島田ら 25)や Forsman ${ }^{29)}$ の興味深い研究がある。島田らはF 涘度の 異なる（45 ppm と225ppm）洗口液を用いた，毎日の洗口実験の結 果, 両者ともさほど连わない効果であったことを報告 し, Forsman は, $0.025 \%$ と.2\%のフッ化ナトリウム （以下 $\mathrm{NaF}$ と略記）溶液を用い, 週 1 回の洗口を行っ たところ，むしろ低源度溶液の方が，やや有効であった ことを示している。

このような事実は，一概にF濃度が高ければ効果も高 いという，比例的関係のないことを示唆するものであ る。一方,このF洗口は主に小学校などの集団を対象に 実施されることが多いため, 洗口液を取り扱うのは養萝 教諭ならびに担任教師など，歯科専門家でないのが一般 的である。このような情況をふまえ，管理面を十分考虑 し，可能な限り低浱度のものを使用する方が望ましいも のといえる。 
Table 3 Dental health program for schoolchildren

\begin{tabular}{l|l}
\hline \multicolumn{1}{c|}{ contents } & \multicolumn{1}{c}{ subjects } \\
\hline survey for dental health behavior & all children \\
dental examination & all children children \\
oral photographing (color) & mainly for parents of screened \\
health education and/or consultation & \\
toothbrushing instruction & mainly for children screened \\
prophylaxis children screened \\
fluoride mouth-rinsing
\end{tabular}

Table 4 Formula of the granule for fluoride mouth-rinsing

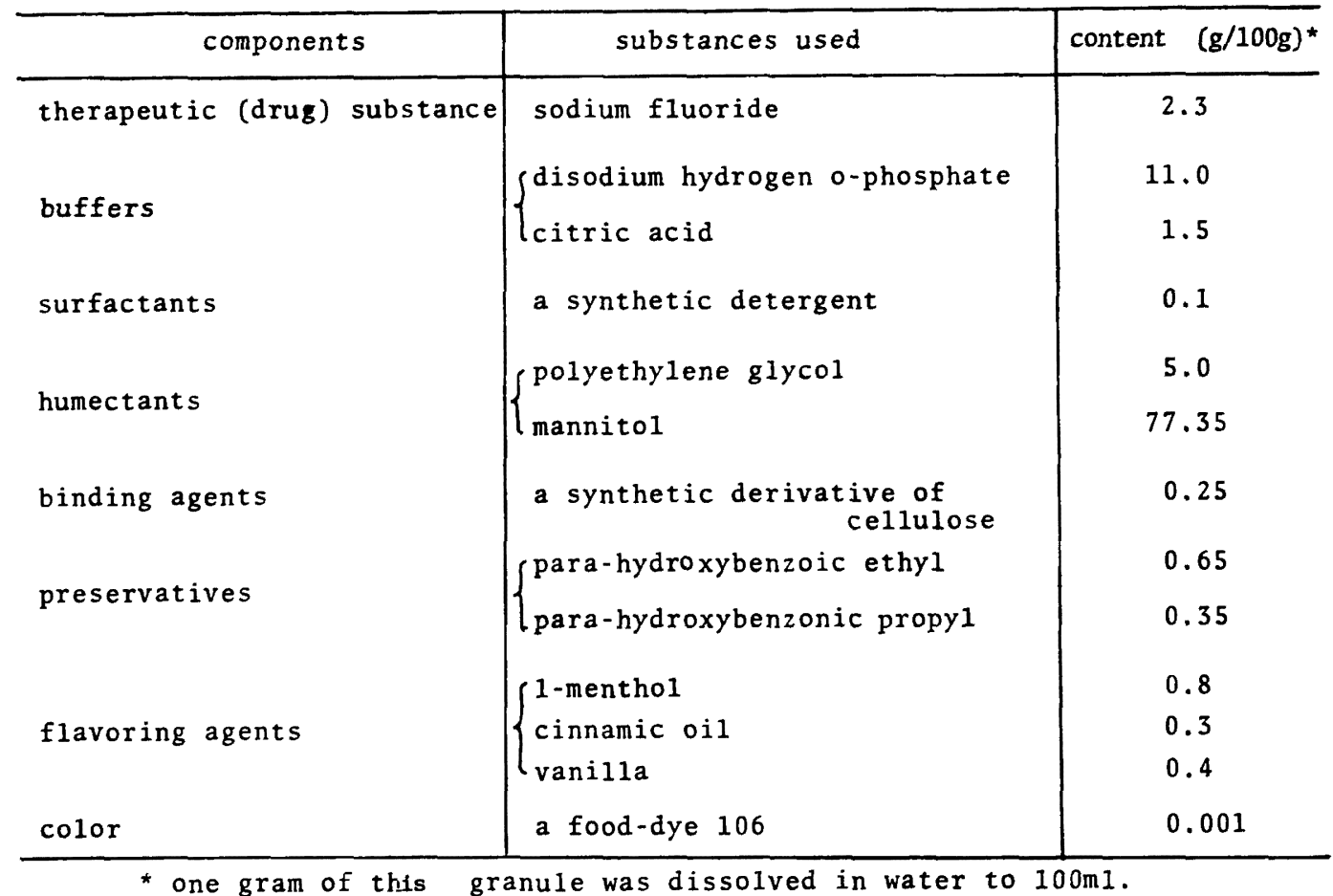

そこで, 従来あまり用いられたことのない，Fとして $100 \mathrm{ppm} と い う$ 低浱度の洗口液を用いて，月曜日から金 曜日までの週 5 回，小学校児童を対象にF洗口を行い, う強抑制効果について検討してみた。

\section{研究材料および方法}

\section{1. 用查対象地域の概略}

調查対象となった地域は, 関東平野のほぼ中央, 首都 圈よりおよそ $50 \mathrm{~km}$ 㢈れた，人口約 40,000 人，面积約 80 


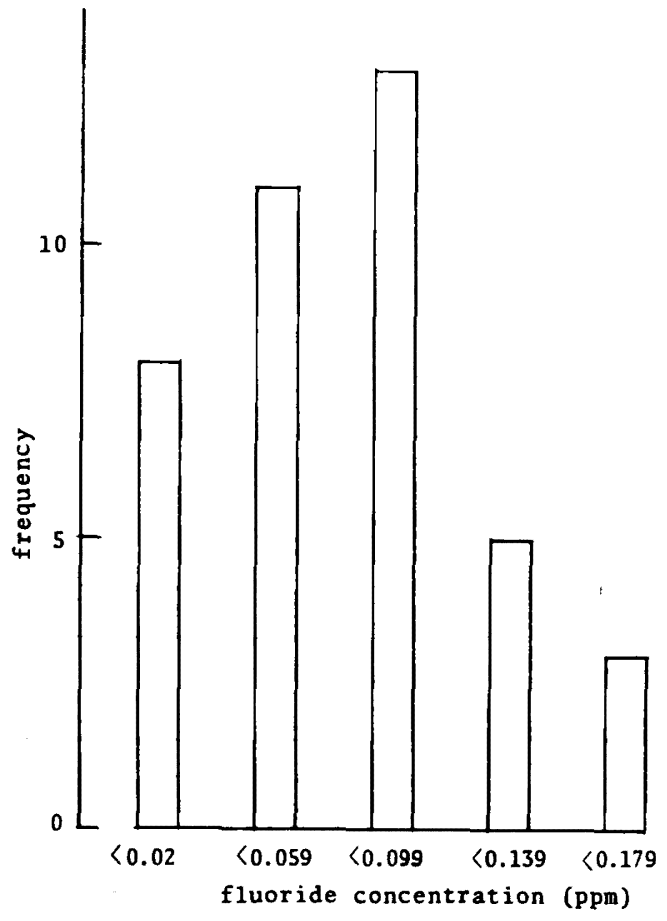

Fig. 1 Distribution of fluoride concentration in drinking water in the neighborhood where the children of school A (fluoride rinsing group) live

$\mathbf{k m}^{2}$ ほどの, 農業と中小の製造業を中心とする落着いた 小都市である。年間の平均気温は $15^{\circ} \mathrm{C}$ 前後であり, そ の他気候的に特㸬な点は見当らない。

また地城の医緳供給状热については，昭和52年と57年 の主なものを Table 2 に示した。齿科の分野では最近 の 5 年間で, 画科診療所 1 力所, 齿科医師 4 名の増加が みられているが, 決してまだ满足できる状態であるとは いいがたい。

\section{2. 思态対象校}

まず調査対象地域にある比較的条件の類似した 2 小学 校を選び，1 校をF洗口校（A小学校とする），他校を 対照校（B小学校とする）として，F洗口以外は全く同 様な齿科保健管理計画を設定した。概略は Table 3 に

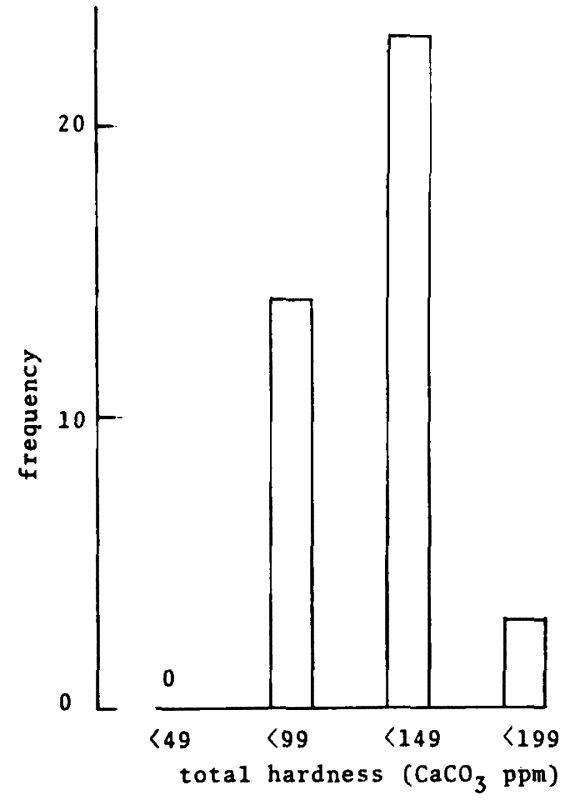

Fig. 2 Distribution of total hardness in drinking water in the neighborhood where the children of school A (fluoride rinsing group) live

示してみたが，個々の内容の詳䋞については他論文 ${ }^{30) に ~}$ 䜇ることにする。

\section{3. 洗口到なびにら洗口液の調整}

$1 \mathrm{~g}$ 中に23mg の $\mathrm{NaF}$ を含有する洗口剂を，学校の 水道水に溶解して洗口液とした。この溶解割合は, $1 \mathrm{~g}$ の洗口剂に対し水 $100 \mathrm{~m} l$ であり， $\mathrm{F}$ として $100 \mathrm{ppm}$ の $\mathrm{NaF}$ 溶液となる。また本溶液の $\mathrm{pH}$ は，洗口绪を蒸留 水で溶解した場合は4.3であったが，実際には学校の水 道水を用いたため，5.0であった。この洗口剤の成分は Table 4 に示すとおりである。

\section{F 洗口方法}

前述したように，A小学校児童を対象に，土曜日と休 日を除く毎日，昼食後に歯みがきを行ってから F 洗口を 実施した。これに対しB小学校では，昼食後の齿みがき とそれにともなう洗口のみ実施し，プラセボ的な洗口は

Table 5 Dates of dental examinations

\begin{tabular}{c|c|c|c|c|c|c|c}
\hline school year & 1977 & 78 & 179 & 180 & 181 & 182 & 183 \\
\hline B (control group) & $5 / 19$ & $5 / 19$ & $6 / 1$ & $6 / 19$ & $6 / 4$ & $4 / 22$ & $3 / 11$ \\
A (fluoride group) & $5 / 20$ & $5 / 18$ & $5 / 31$ & $6 / 20$ & $6 / 5$ & $4 / 23$ & $3 / 11$ \\
\hline
\end{tabular}


Table 6 A questionnarire for dental health behavior

\begin{tabular}{|c|c|c|c|c|c|}
\hline & items & & answer & & \\
\hline & $\begin{array}{l}\text { taste for sweet foods } \\
\text { and drinks }\end{array}$ & (a) like & (b) dislike & (C) average & \\
\hline$n$ & kind of snacks & (a) sweets & (b) non-sweets & (c) both & \\
\hline 樬 & times per day & (a) 0 & (b) 1 & (c) 2 & (d) 3 or above \\
\hline & regularity & (a) $\begin{array}{l}\text { at set } \\
\text { times }\end{array}$ & (b) ad libitum & $\begin{array}{l}\text { neither of } \\
\text { (2) nor(b) }\end{array}$ & \\
\hline & volume per day & (a) little & (b) much & (C) average & \\
\hline$\stackrel{\infty}{c}$ & regularity & (a) daily & (b) rarely & (C)occasionally & \\
\hline : & times per day & (a) 0 & (b) 1 & (c) 2 & (d) 3 or above \\
\hline$\stackrel{+}{+}$ & methods & (a) as taught & $\begin{array}{l}\text { (b) in one's } \\
\text { own way }\end{array}$ & (c) don't know & \\
\hline
\end{tabular}

Table 7 Number of schoolchildren participated in the dental health program

\begin{tabular}{|c|c|c|c|c|c|c|c|c|c|c|c|c|}
\hline school & \multicolumn{6}{|c|}{ A (fluoride group) } & \multicolumn{6}{|c|}{ B (control group) } \\
\hline theyear & 1977 & $' 78$ & 179 & 180 & 181 & 182 & 1977 & 178 & 179 & 180 & $' 81$ & 82 \\
\hline 1 & 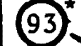 & 91 & 118 & 110 & 103 & 96 & & 73 & 77 & 83 & 87 & 88 \\
\hline 2 & 66 & & 101 & 123 & 104 & 104 & 61 & & 69 & 84 & 82 & 89 \\
\hline 3 & 97 & 65 & & 97 & 121 & 106 & 85 & 62 & & 70 & 82 & 83 \\
\hline 4 & 75 & 93 & 70 & & 97 & 123 & 67 & 87 & 60 & & 70 & 82 \\
\hline 5 & 75 & 79 & 99 & 69 & & 98 & 57 & 70 & 90 & 64 & & 70 \\
\hline 6 & 78 & 80 & 83 & 105 & 72 & 60 & 51 & 59 & 75 & 91 & 65 & \\
\hline total & 484 & 504 & 568 & 604 & 594 & 627 & 391 & 421 & 440 & 461 & 456 & 482 \\
\hline
\end{tabular}

* The numbers in circles indicate children who participated continuously in the dental health program for 6 years.

These children were analyzed in this report. 
Table 8 Period of participation of the target group children

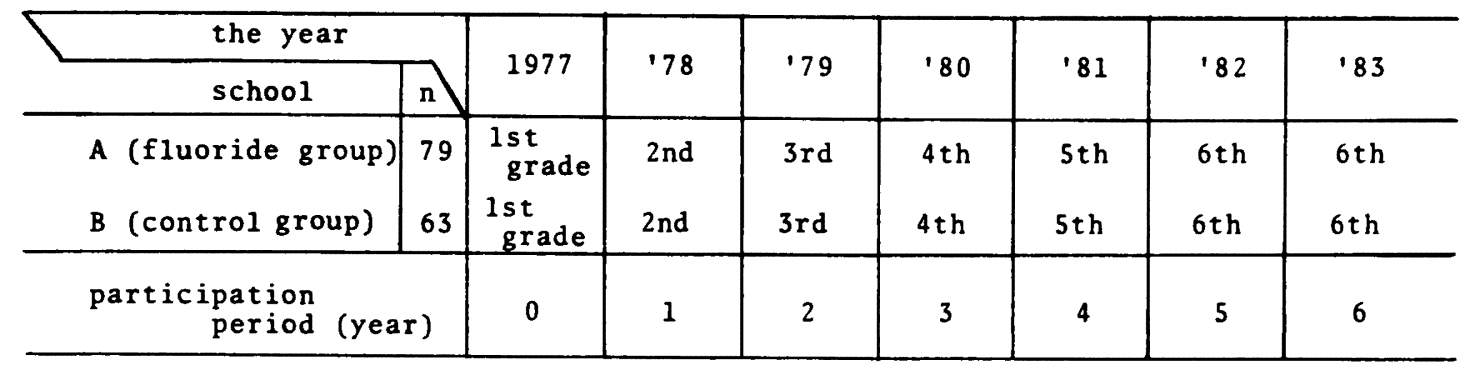

Table 9-1 Results of survey for dental health behavior-snacks

\begin{tabular}{|c|c|c|c|c|c|}
\hline \multirow{3}{*}{ items } & \multirow{3}{*}{ answer } & \multicolumn{2}{|c|}{$\begin{array}{l}\text { school A } \\
\text { (fluoride group) }\end{array}$} & \multicolumn{2}{|c|}{$\begin{array}{l}\text { school B } \\
\text { (control group) }\end{array}$} \\
\hline & & parti & ipatior & period & (year) \\
\hline & & 0 & 5 & 0 & 5 \\
\hline $\begin{array}{l}\text { taste for } \\
\text { sweet foods } \\
\text { and drinks }\end{array}$ & $\begin{array}{l}\text { (a) like } \\
\text { (b) dislike } \\
\text { (c) average }\end{array}$ & $\begin{array}{c}37.08 \\
6.8 \\
56.2\end{array}$ & $\begin{array}{l}22.8 \% \\
1.3 \\
75.9\end{array}$ & $\begin{array}{l}37.18 \\
6.5 \\
56.5\end{array}$ & $\begin{array}{l}28.68 \\
3.2 \\
68.3\end{array}$ \\
\hline $\begin{array}{l}\text { kind of } \\
\text { snacks }\end{array}$ & $\begin{array}{l}\text { (a) sweets } \\
\text { (b) non-sweets } \\
\text { (c) both }\end{array}$ & $\begin{array}{l}10.5 \\
10.5 \\
79.1\end{array}$ & $\begin{array}{r}5.1 \\
8.9 \\
86.1\end{array}$ & $\begin{array}{r}9.1 \\
13.6 \\
77.3\end{array}$ & $\begin{array}{r}3.2 \\
7.9 \\
88.9\end{array}$ \\
\hline $\begin{array}{l}\text { times per } \\
\text { day }\end{array}$ & $\begin{array}{l}\text { (a) } 0 \\
\text { (b) } 1 \\
\text { (c) } 2 \\
\text { (d) } 3 \text { or above }\end{array}$ & $\begin{array}{c}0 \\
50.7 \\
49.3 \\
0\end{array}$ & $\begin{array}{r}2.5 \\
63.3 \\
31.6 \\
2.5\end{array}$ & $\begin{array}{r}1.7 \\
51.7 \\
37.9 \\
8.6\end{array}$ & $\begin{array}{r}1.6 \\
47.6 \\
39.7 \\
11.1\end{array}$ \\
\hline regularity & $\begin{array}{l}\text { (a) at set } \\
\text { times } \\
\text { (b) ad libitum } \\
\text { (c) neither of } \\
\text { (a) nor b) }\end{array}$ & $\begin{array}{l}36.6 \\
43.7 \\
19.7\end{array}$ & $\begin{array}{r}8.9 \\
46.8 \\
44.3\end{array}$ & $\begin{array}{c}16.4 \\
83.6 \\
0\end{array}$ & $\begin{array}{r}4.8 \\
50.0 \\
45.2\end{array}$ \\
\hline $\begin{array}{l}\text { volume per } \\
\text { day }\end{array}$ & $\begin{array}{l}\text { (a) little } \\
\text { (b) much } \\
\text { (c) average }\end{array}$ & $\begin{array}{r}9.6 \\
82.2 \\
8.2\end{array}$ & $\begin{array}{r}8.9 \\
84.8 \\
6.3\end{array}$ & $\begin{array}{r}4.9 \\
91.8 \\
3.3\end{array}$ & $\begin{array}{r}7.9 \\
87.3 \\
4.8\end{array}$ \\
\hline
\end{tabular}

特に行わなかった。洗口液の調整は, 恶讙教諭が保健室 で行い，各クラスへの分配は保健委員が担当した。各ク ラスでは, 担任教師の監督の下に, 各自洗ロカップに10 $\mathrm{ml}$ ずつ分注し、30秒間の洗口後, 流しに吐き出した。 1 年間の洗口回数はおよそ200回となる。

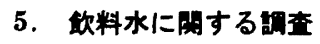


Table 9-2 Results of survey for dental health behavior-toothbrushing

\begin{tabular}{|c|c|c|c|c|c|}
\hline \multirow{3}{*}{ items } & \multirow{3}{*}{ answer } & \multicolumn{2}{|c|}{$\begin{array}{l}\text { school A } \\
\text { (fluoride group) }\end{array}$} & \multicolumn{2}{|c|}{$\begin{array}{l}\text { school B } \\
\text { (contral group) }\end{array}$} \\
\hline & & \multicolumn{4}{|c|}{ participation period (year) } \\
\hline & & 0 & 5 & 0 & 5 \\
\hline regularity & $\begin{array}{l}\text { (a) daily } \\
\text { (b) rarely } \\
\text { (c)occasionally }\end{array}$ & $\begin{array}{r}80.3 q \\
2.8 \\
16.9\end{array}$ & $\begin{array}{c}75.98 \\
0 \\
24.1\end{array}$ & $\begin{array}{r}77.08 \\
4.9 \\
18.0\end{array}$ & $\begin{array}{l}66.7 \% \\
1.6 \\
31.7\end{array}$ \\
\hline $\begin{array}{l}\text { times per } \\
\text { day }\end{array}$ & $\begin{array}{l}\text { (a) } 0 \\
\text { (b) } 1 \\
\text { (c) } 2 \\
\text { (d) } 3 \text { or above }\end{array}$ & $\begin{array}{c}0 \\
53.4 \\
45.2 \\
1.4\end{array}$ & $\begin{array}{c}0 \\
12.7 \\
74.7 \\
12.7\end{array}$ & $\begin{array}{c}1.6 \\
71.0 \\
27.4 \\
0\end{array}$ & $\begin{array}{r}3.2 \\
39.7 \\
54.0 \\
1.6\end{array}$ \\
\hline methods & $\begin{array}{l}\text { (a) as taught } \\
\text { (b) in one's } \\
\text { own way } \\
\text { (c) don't know }\end{array}$ & $\begin{array}{l}73.2 \\
15.5 \\
11.3\end{array}$ & $\begin{array}{r}54.4 \\
44.3 \\
1.3\end{array}$ & $\begin{array}{l}78.0 \\
10.2 \\
11.9\end{array}$ & $\begin{array}{r}39.7 \\
50.8 \\
9.5\end{array}$ \\
\hline
\end{tabular}

A小学校でのF洗口開始に先立ち，同校児童が日常飲 用する水のF搌度と総硬度について調へたた。12地区から

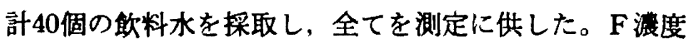

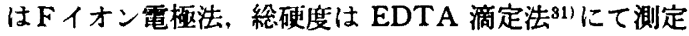
し結果は Fig. 1・2 に度数分布で示した。

F 搌度の最高值は0.155ppm であり，ほとんどが0.1p $\mathrm{pm}$ 以下であった。また総硬度の平均は105ppm と，フ ッ化物の応用に際し，特簕すへき問題点はなかった。な お B 小学校の饮料水中 $\mathrm{F}$ 湄度も，A小学校とほぼ同様な 値であった。

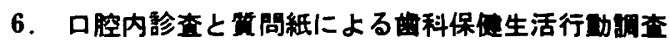
毎年度の 5 月頃，複数の歯科医師により，歯鏡，探針 および人工照明を用いた視診型口腔内詮查を実施した。

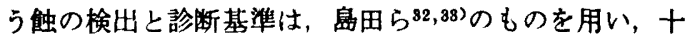
分な打ち合わせと訓練の後に，歯面別に診查した。なお 昭和57年度末の 3 月に， 6 年生のみの口腔内診查を行 い, 開始後 6 年の最終的な結果とした (Table 5 参照)。

また各年度初めには，犋問紙による苗科保健生活行動 調查を㝇 6 回実施した。この調查項目のうち，昭和52年 度から57年度まで，一貲した内容であった質問事項とそ の回答枝を Table 6 に示した。記入注父が行い，回収 率は100\%であった。

\section{7. テータの分析方法}

この歯科保健管理活動に参加したA・B小学校の年度 別児童数を Table 7 に示した。男女の内訳は示してい ないが，両校ともに男子の方がやや多い程度であり，各 年度間で大きな変動はなかった。この表中，丸印を付し た学年を今回の分析対象としたが，昭和52年度の 1 年次 から昭和57年度末の 6 年次に実施した最終口腔内詮査ま で継続的に参加した児童に限定したため，Table 8 に示 したようにA小学校79名, B小学校63名が分析対象人数 となった。また Table 5 を参照にするとわかるように, 保健管理経験年数はほほ Table 8下段に示すようにな り, 便宜上, 以後の説明には，この経験年数を用いるこ とにする。

またう蝕抑制事は, 初年度のう赨状況に若干の差があ るため，以下の算出式により求めたものである。

う蝕抑制率 $=\frac{B-A}{B}(\%)$

$$
\left\{\begin{array}{c}
\mathrm{A} ; \mathrm{A} \text { 小学校における 各経験年数ごとの } \mathrm{DMF} \\
\text { 指数一初年度の DMF 指数 } \\
\mathrm{B} ; \mathrm{B} \text { 小学校における 各経験年数ごとの } \mathrm{DMF} \\
\text { 指数一初年度の DMF 指数 }
\end{array}\right.
$$

つまり，初年度をベースラインデータとして，その増 加から抑制率を求めたわけである。

またデータ分析方法については，調查項目が多岐にわ 
Table 10 Scoring for dental health behavior

\begin{tabular}{|c|c|c|c|}
\hline \multicolumn{2}{|c|}{ items } & answer & score \\
\hline \multirow{5}{*}{ 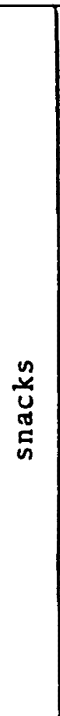 } & $\begin{array}{l}\text { taste for sweet } \\
\text { foods and drinks }\end{array}$ & $\begin{array}{l}\text { (b) dislike } \\
\text { (C) average } \\
\text { (a) like }\end{array}$ & $\begin{array}{c}0.5 \\
1 \\
1.5 \\
\end{array}$ \\
\hline & kind of snacks & $\begin{array}{l}\text { (b) non-sweets } \\
\text { (C) both } \\
\text { (a) sweets }\end{array}$ & $\begin{array}{c}0.5 \\
1 \\
1.5 \\
\end{array}$ \\
\hline & times per day & $\begin{array}{l}\text { (a) } 0 \\
\text { (b) } 1 \\
\text { (c) } 2 \\
\text { (d) } 3 \text { or above }\end{array}$ & $\begin{array}{c}0.5 \\
1 \\
1.5\end{array}$ \\
\hline & regularity & $\begin{array}{l}\text { (a) at set times } \\
\text { () neither of (a)nor(b) } \\
\text { (b) ad libitum }\end{array}$ & $\begin{array}{c}0.5 \\
1 \\
1.5\end{array}$ \\
\hline & volume per day & $\begin{array}{l}\text { (a) little } \\
\text { (C) average } \\
\text { (b) much }\end{array}$ & $\begin{array}{c}0.5 \\
1 \\
1.5\end{array}$ \\
\hline \multirow{3}{*}{ 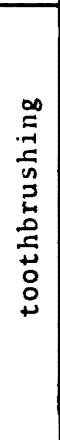 } & regularity & $\begin{array}{l}\text { (a) daily } \\
\text { (c) occasionally } \\
\text { (b) rarely }\end{array}$ & $\begin{array}{c}0.5 \\
1 \\
1.5 \\
\end{array}$ \\
\hline & times per day & $\begin{array}{l}\text { (d) } 3 \text { or above } \\
\text { (C) } 2 \\
\text { (b) } 1 \\
\text { (a) } 0\end{array}$ & $\begin{array}{c}0.5 \\
1 \\
1.5 \\
\end{array}$ \\
\hline & methods & $\begin{array}{l}\text { (a) as taught } \\
\text { (C) don' } t \text { know } \\
\text { (b) in one's own way }\end{array}$ & $\begin{array}{c}0.5 \\
1 \\
1.5\end{array}$ \\
\hline
\end{tabular}

たっているため，研究成績の項でその都度述べることに する。

\section{研究成縤}

\section{1. 蒾科保健生活行動的查の結果}

Table 9-1 $\cdot 2$ に昭和 52 年度（経験年数 0 年）と昭和 57 年度 (経験年数 5 年)の菌科保健生活行動調查結果を示 した。これをみると，5年間にわたる歯科保健管理によ り，両校とも改善された点と逆に悪くなった点が見受け られ，集団に対する药科保健生活指導の難しさを物語っ ているようである。このように大きな変化を示した項目 はないながらも，改善された部分として特記すべき部分 は9-1の1 日の間食回数と 9-2の1日の画みがき回数 である。また悪くなった部分としては 9-1の間食の与 え方と 9-2 の歯みがき方法をあげることができる。
さらにA・B両小学校を比較してみると, 概して A小 学校の方が良好な菌科保健生活状態にあるといえるが, これは初年度からの傾向であり，その変化率としては， さほど差はないものと思われる。

2. 酋科保健生活行動と DMFT 指数の相関について ここでは, 渵科保健生活行動とう触との間にどの程度 の関係があるかを調べてみた。しかしながら，倎問紙に よるアンケート調查の信頼性94,95)などを考虑すると、こ の分析は非常に難しいものとなる。そこで次のような方 法により分析してみた。まず Table 10のように，う蝕 に対して促進的な影響を与えると思われる歯科保健生活 行動には1.5点, 逆に抑制的な要因は0.5点, 中間的要因に は 1 点という便宜的な点数設定を行った。ついで経験年 数 $0 \sim 5$ 年まで, 計 6 回にわたる調查結果にこの点数を 代入し，8調查項目別に平均した。こうして得られた点 
TPble 11 Correlation between dental health behavior and DMFT index

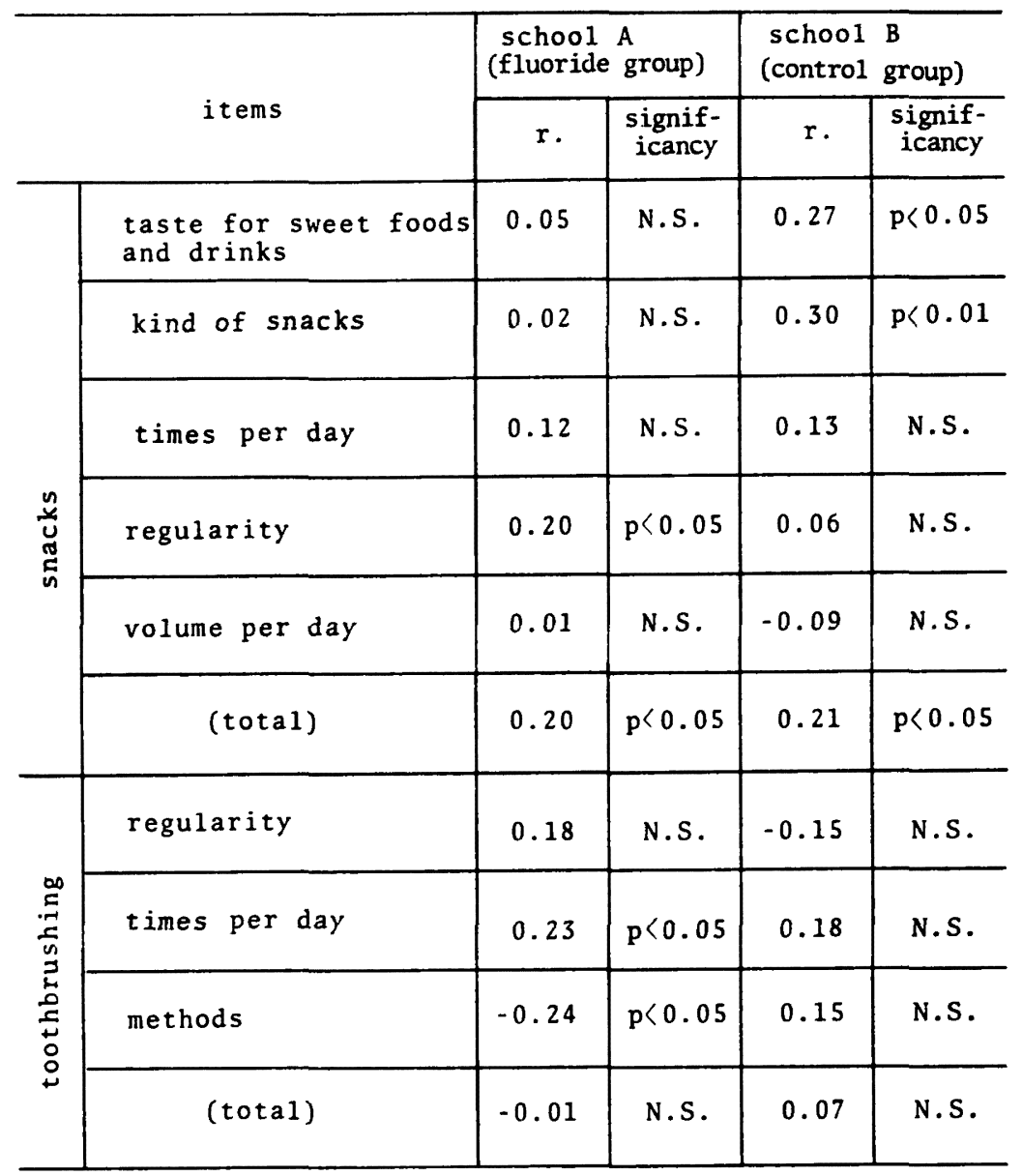

Table 12 The year-course of caries experience during the dental health program

\begin{tabular}{|c|c|c|c|c|c|c|c|c|}
\hline \multirow{2}{*}{ school } & \multirow{2}{*}{ indices } & \multicolumn{7}{|c|}{ participation period (years) } \\
\hline & & 0 & 1 & 2 & 3 & 4 & 5 & 6 \\
\hline \multirow{3}{*}{$\begin{array}{c}\text { A } \\
\text { (fluoride } \\
\text { group) }\end{array}$} & $\begin{array}{lll}\text { prevalence rate } & \\
& \text { of DMF } \quad(\xi)\end{array}$ & 44.3 & 63.3 & 74.7 & 79.7 & 82.3 & 78.5 & 82.3 \\
\hline & DMFT index & 0.94 & 1.35 & 1.57 & 2.14 & 2.08 & 2.29 & 2.90 \\
\hline & DMFS index & 1.22 & 1.87 & 2.25 & 3.16 & 3.33 & 4.01 & 4.87 \\
\hline \multirow{3}{*}{$\begin{array}{c}\text { B } \\
\text { (control } \\
\text { group) }\end{array}$} & $\begin{array}{lll}\text { prevalence rate } & \\
& \text { of DMF }(q)\end{array}$ & 41.3 & 60.3 & 71.4 & 81.0 & 88.9 & 87.3 & 92.1 \\
\hline & DMFT index & 0.84 & 1.54 & 2.03 & 2.78 & 3.33 & 3.30 & 4.94 \\
\hline & DMFS index & 0.95 & 2.06 & 3.00 & 4.62 & 5.32 & 6.17 & 8.40 \\
\hline
\end{tabular}




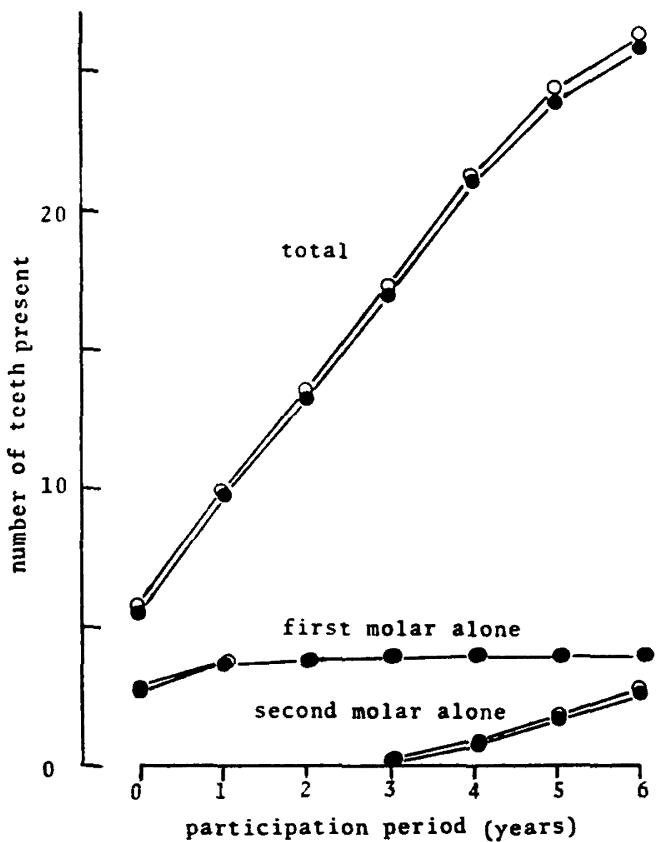

Fig. 3 Number of permanent teeth - school A (fluoride group) O-O school B (control group)

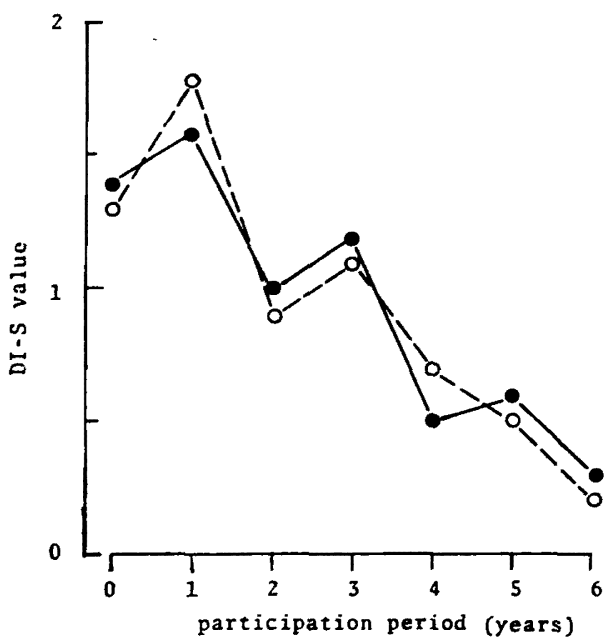

Fig. 4 The year-course of the DI-S value - school A (fluoride group) O-- - O school B (control group)

数と, 経験 6 年次の DMFT 指数との相関を調べたわ けである。

結果は Table 11であり，なかには弱い相関を示した
項目もあるが，ほとんどのものは関係がなさそうであ る。要約すれば，間食とう触とには弱い相関があるが， 齒みがきに関しては，今回の調査では関連性を見い出せ なかったといえる。

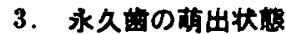

ここでは，菌の萠出時期がう钟発生に与える影響を考

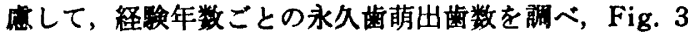
に全永久歯数と特にう䖵感受性の高い第一・第二大目歯 をとりあげ，その萌出歯数を示した。この結果，萌出永 久歯数は毎年ほほ直線的に増加しており，両校ともほぼ 同様な萌出状態であることがわかった。その他特に問題 となる点はないようである。

\section{4. 甚口清㛿状態について}

口腔内趁查時にあわせて，OHI-S の判定も実施して おり,このうち DI.S の変化について Fig. 4 に示して みた。これは検查対象歯 $\left(\begin{array}{ll|l}6 & 1 & 6 \\ \hline 6 & 16\end{array}\right)$ が萠出している 児童のみが被検者となったため， $1 \cdot 2$ 年生次の対象人 数は少ないが， 3 年生以降はほほ全数が対象となってい る。これをみると，年をおうごとに両校の龂口清掃状 態は改善されているが，両校間に差はないことがわか る。

以上の上うに両校間の地域性, 歯科保健生活行動, 永

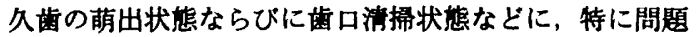
となる差が見当らないことから，両校児童の永久歯う強 状況を追跡検郡することにより，歯科保健管理計画のう ち，唯一方法を異にしていた低湍度フッ化物溶液による 洗口のう䖵抑制効果について，追求できるものと思われ た。

\section{DMF 指數について}

口腔内診查結果をもとに，経験年数ごとの DMF 所 有者事, DMFT 指数および DMFS 指数を求め, Table 12に示した。また保健管理を受けていない初年度におい ては，ややA小学校におけるう䖵の方が多い状態であっ たが，有意なものではない。その後の推移をたどると， DMFT 指数と DMFS 指数は経㖇年数 1 年で，また DMF 所有者率では経弱年数 3 年より逆転しているのが かかる。これはF洗口により，A小学校児童のう触発生 がかなり抑制されていることを亭うけるものであるが， DMF 所有者率のように，人という大きな単位でう触を あらわした場合，その抑制効果が発現されるまでには， ある程度の期閒を要することを示唆するものである。ま た DMFT 率および DMFS 率については，両校間の 萌出苗数に差がないことから省略した。

さらに，研究方法の項で説明した算出方法に基うき， 
Table 13 The year-course of caries reduction rate (\%) through fluoride mouth-rinsing

\begin{tabular}{c|c|c|c|c|c|c}
\hline \multirow{2}{*}{\begin{tabular}{c}
\multirow{2}{*}{ indices } \\
\cline { 2 - 7 }
\end{tabular}} & \multicolumn{5}{|c|}{ participation period (years) } \\
\cline { 2 - 7 } DMFT index & 1 & 2 & 3 & 4 & 5 & 6 \\
\hline DMFS index & 41.4 & 56.0 & 38.1 & 54.2 & 45.1 & 52.2 \\
\hline
\end{tabular}

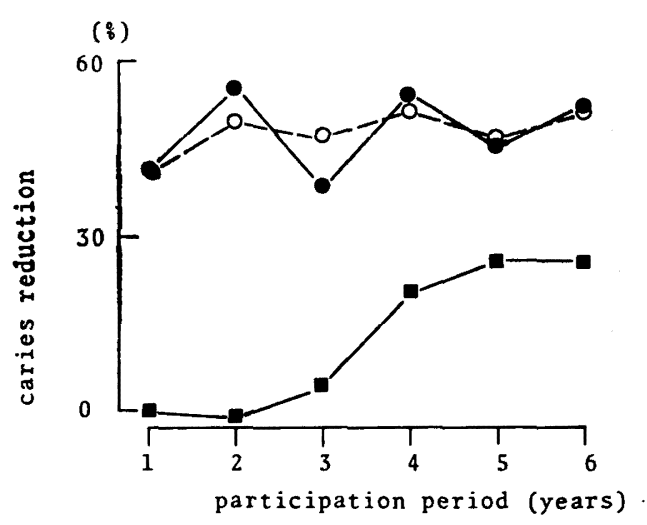

Fig. 5 The year-course of caries reduction rate in the fluoride group

- DMFT index

O---O DMFS index

prevalence rate of DMF
各程験年数のう的抑制率を求め, Table 13 と Fig. 5 に示した。DMFT 指数の抑制率をみると，経験年数 1 年次から 6 年次までほほ横ばいの状態であり，40 55\% の笵囲で变動している。このように，歯という比較的小 さな単位の指数の場合は, すぐに抑制効果が現われてく るのに対し，さきほども説明したが, DMF 所有者率の 抑制勃果はかなり遅れて発現してくる状热がよくか る。経験年数 $4 \cdot 5$ 年目頃から, やっと横ばいになるよ うである。

さらに, DMFT 指数の推移のみをとりあげ, 有意差 検定の結果とともに Fig. 6 に示した。経験年数 5 年次 に診断の逆転がみられるが，4年以降は高度に有意な差 があらわれているのがわかる。

6. 小裂清・平消面別の DMFS 指数について

便宜上, Fig. 7 のように永久齔を小窝裂满と平滑面に 分け，それぞれに対する抑制訤果について検討した。結

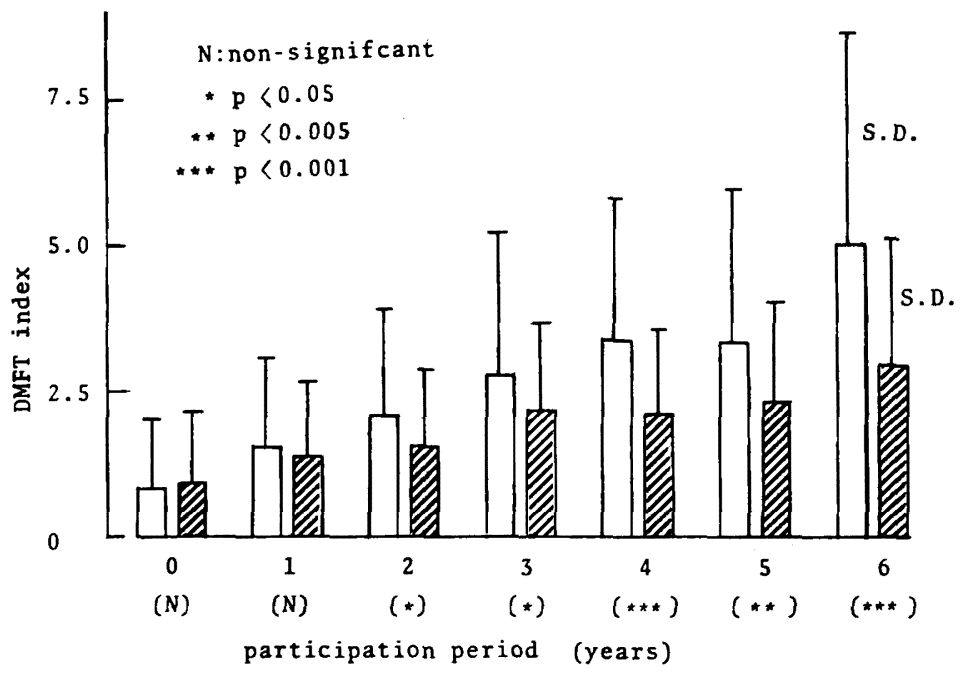

Fig. 6 The year-course of DMFT index school A (fluoride group) school B (control group) 


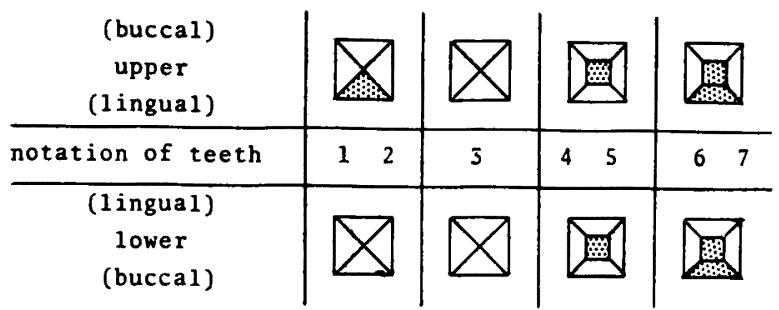

smooth surfaces

Fig. 7 Criteria of pits-and-fissures or smooth surfaces in each tooth type

果は前の DMF 指数と同様に Table 14・15ならびに Fig. 8に示してあるが， 従来からの報告のように18,27， 36,37)，小筒裂海よりも平滑面に対する効果の方が大きい ようであった。しかし Table 14をみるとわかるように， 平滑面にう蝕が見られ始めるのは小学校 3 年（経験年数 2 年）目頃からであり，経験年数 1 年次の差は本来のも のではないものと思われる。6 年後の最終的な結果は小 窝裂满 $43.8 \%$ ，平滑面65.8\%という抑制事であった。

\section{7. 第一大曰曾と第二大曰菌の DMF 指数について}

ここでは, 永久画のうち, 特にう強感受性の高い第一

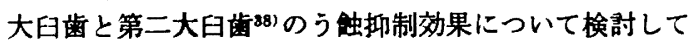
みた。Table 16に第一大臼齿と第二大田歯別の DMFT 指数を，また Table 17には両者総計の DMFS 指数を 示したが，第二大曰歯は萌出時期が遅いため DMF 歯 も少なく，経験年数 6 年次においても A B B両小学校の 差は判然としない。一方萌出時期が早く，学童期におけ るう蝕の大部分を占める ${ }^{29}$ 第一大臼歯に対して，小学校 入学時からF洗口を開始した場合, どの程度の抑制勃果 が得られるものか興味のもたれるところであるが, Fig. 9 にその抑制率を示した。多少の変動はあるものの，第 一大臼歯う蝕の抑制率は $35 \%$ 前後であり，これ以外の永 久歯の抑制率と比べるとかなり低い上うである。しかし
(8)

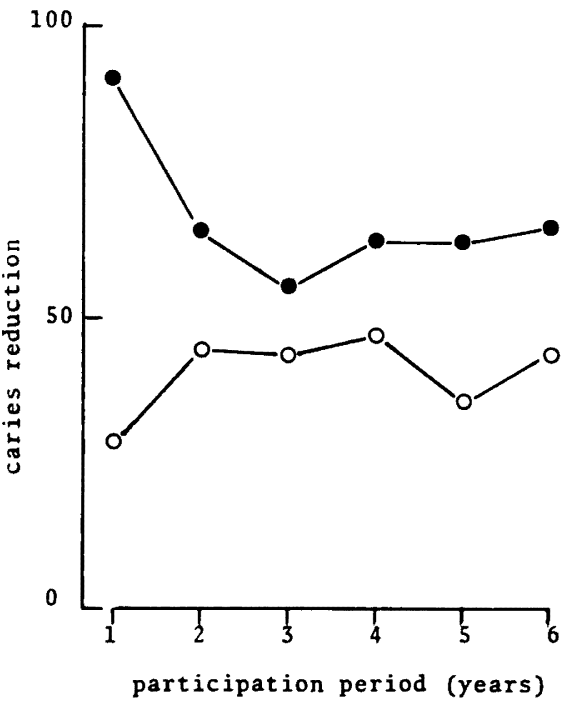

Fig. 8 The year-course of caries reduction rate in the fluoride group as DMFS indices separated according to pits-andfissures and smooth surfaces ○—O smooth surfaces

他の永久歯の抑制率も，経験年数の増加にともない低下 してくる傾向があり，さらに経験年数が延長すれば，そ の差はますます縮まってゆくことが予想される。ところ が Fig. 10のように第二大臼齿も加えてみると, 経験年 数 4 年目頃からはほぼ平行関係にあるようで, ここらあ たりが，小窝裂清う蝕を主とする第一・第二大臼歯う䖵 と他永久踩う钟との抑制効果の差となるのであろう。い すれれにしても，特にう䖵感受性の高い第一・第二大白歯 に対しても35\%程度のう触抑制効果は期待できそうであ る。これ以上の奻果を望む場合は，F曝蕗開始時期を歯

Table 14 The year-course of DMFS index separated according to pits-and-fissures or smooth surfaces

\begin{tabular}{c|c|c|c|c|c|c|c|c}
\hline \multirow{2}{*}{ school } & \multirow{2}{*}{ tooth surface } & \multicolumn{5}{|c}{ participation period (years) } \\
\cline { 3 - 8 } & & 0 & 1 & 2 & 3 & 4 & 5 & 6 \\
\hline \multirow{2}{*}{ A (fluoride group) } & pits-and-fissures & 1.04 & 1.67 & 1.90 & 2.52 & 2.67 & 3.05 & 3.86 \\
\cline { 2 - 9 } & smooth-surfaces & 0.18 & 0.20 & 0.35 & 0.65 & 0.66 & 0.96 & 1.01 \\
\hline \multirow{2}{*}{ B (control group) } & pits-and-fissures & 0.95 & 1.83 & 2.51 & 3.57 & 4.02 & 4.06 & 5.97 \\
\cline { 2 - 9 } & smooth surfaces & 0 & 0.24 & 0.49 & 1.05 & 1.30 & 2.11 & 2.43 \\
\hline
\end{tabular}


Table 15 The year-course of caries reduction rate (\%) with DMFT index separated according to pits-and-fissures or smooth surfaces through fluoride mouth-rinsing

\begin{tabular}{l|c|c|c|c|c|c}
\hline \multirow{2}{*}{ tooth surface } & \multicolumn{5}{|c|}{ participation period (years) } \\
\cline { 2 - 7 } & 1 & 2 & 3 & 4 & 5 & 6 \\
\hline pits-and-fissures & 28.4 & 44.9 & 43.5 & 46.9 & 35.4 & 43.8 \\
\hline smooth surfaces & 91.7 & 65.3 & 55.2 & 63.1 & 63.0 & 65.8 \\
\hline
\end{tabular}

Table 16 The year-course of DMFT index of first or second molars during the dental health program

\begin{tabular}{l|c|c|c|c|c|c|c|c}
\hline \multirow{2}{*}{ teeth } & \multirow{2}{*}{ school } & \multicolumn{6}{|c}{ participation period (years) } \\
\cline { 3 - 9 } & & 0 & 1 & 2 & 3 & 4 & 5 & 6 \\
\hline \multirow{3}{*}{1 st molar } & A (fluoride group) & 0.94 & 1.35 & 1.52 & 1.99 & 1.92 & 2.00 & 2.22 \\
\cline { 2 - 9 } & B (control group) & 0.84 & 1.51 & 1.79 & 2.19 & 2.60 & 2.35 & 2.81 \\
\hline \multirow{2}{*}{ 2nd molar } & A (fluoride group) & 0 & 0 & 0 & 0 & 0 & 0.14 & 0.41 \\
\cline { 2 - 9 } & B (control group) & 0 & 0 & 0 & 0.02 & 0.06 & 0.08 & 0.78 \\
\hline
\end{tabular}

Table 17 The year-course of DMFS index and caries reduction rate (\%) in molars (1st and 2 nd molar) and all other teeth

\begin{tabular}{|c|c|c|c|c|c|c|c|c|}
\hline \multirow{2}{*}{ teeth } & \multirow{2}{*}{ school } & \multicolumn{7}{|c|}{ participation period (year) } \\
\hline & & 0 & 1 & 2 & 3 & 4 & 5 & 6 \\
\hline \multirow[b]{2}{*}{1 st and 2 nd molar } & A (fluoride group) & 1.19 & 1.85 & 2.19 & 2.95 & 3.13 & 3.77 & 4.47 \\
\hline & B (control group) & 0.95 & 1.98 & 2.63 & 3.65 & 4.37 & 4.54 & 6.11 \\
\hline \multicolumn{3}{|c|}{ caries reduction rate $(\xi)$} & 35.9 & 40.5 & 34.8 & 43.3 & 28.1 & 36.4 \\
\hline \multirow{3}{*}{ other teeth } & A (fluoride group) & 0.03 & 0.03 & 0.06 & 0.22 & 0.20 & 0.24 & 0.41 \\
\hline & B (control group) & 0 & 0.08 & 0.34 & 0.97 & 0.95 & 1.63 & 2.29 \\
\hline & \multicolumn{2}{|c|}{ caries reduction rate $(q)$} & 100 & 91.1 & 80.4 & 82.1 & 87.1 & 83.4 \\
\hline
\end{tabular}

牙萌出開始前からにする ${ }^{13,28)}$ ，または小窝裂漸に対する フィッシャーシーラントの応用(11,42) などを考えるべきで あろう。

8. 初年度既葫出永久蔽の新生 DMFT 指数について 初年度（経験年数 0 年）の口腔内晾查時に萠出してい た永久歯のうち，既にう触であると診断された歯を除い
た場合の新生 DMFT 指数の推移を Table 18に示し た。既萌出歯のほとんどは第一大臼歯であり，A小学校 における新生 DMFT 指数のほぼ100\%を占めていた。 これに対し B小学校においては，最終時点で $78.4 \%$ 之第 一大鼠以外の永久菌にも，かなりの新生う強が発生し ているようであった。 
(3)

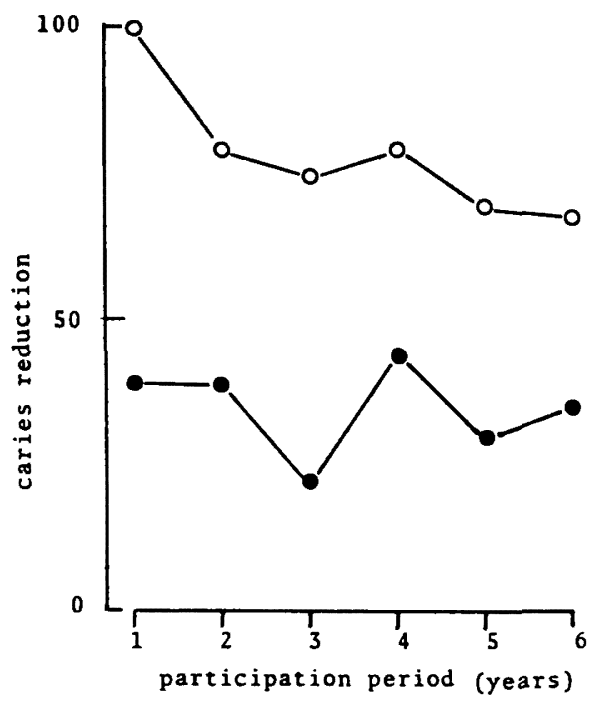

Fig. 9 The year-course of caries reduction rate in the fluoride group as DMFT index expressed with first molar or all other teeeth

- - first molar

$0-O$ all teeth other than first molar

(3)

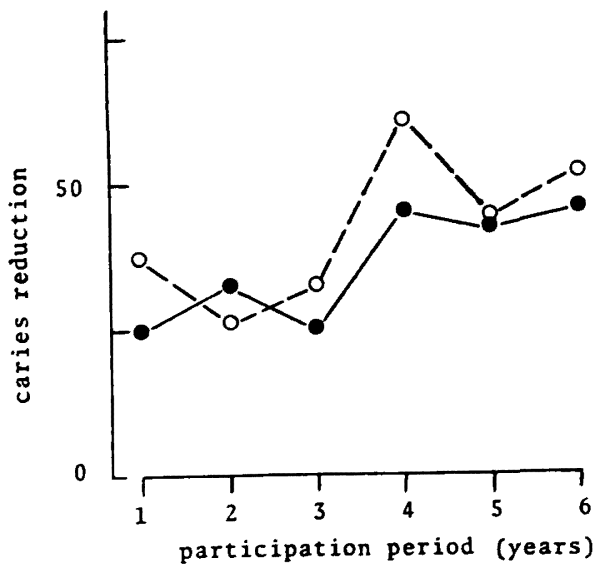

Fig. 11 The year-course of carise reduction rate in the fluoride group as DMFT index expressed with newly or previously erupted teeth

- - previously erupted teeth O- - O newly erupted teeth
(8)

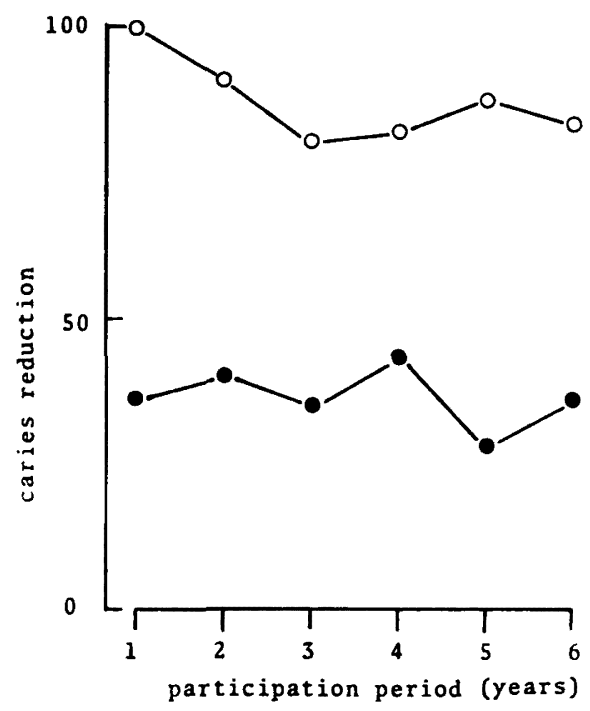

Fig. 10 The year-course of caries reduction rate in the fluoride group as DMFS index expressed with molars (first and second molar) or all other teeth - first and second molars 0 - $O$ all teeth other than molars

9. 初年度末葫出永久曾の新生 DMFT 指数について

こんどは，初年度（経釦年数 0 年）の口腔内診查時に 未萌出であった承久歯の新生 DMFT 指数の推移を Table 19に示した。A小学校において新萌出齿にう蝕発 生がみられたのは，経験年数 6 年の全永久歯で1.13齿と わずかであるが， B小学校では2.37歯であった。両校の 差は経験年数 4 年次より大きく広がるようであった。

また第一大臼歯の占める割合は，さきほどと同棣に $\mathrm{B}$ 小学校の方が低く，他永久歯のう触がかなり発生してい ることを衰ゔけている。

10. 初年度既荫出永久菌および末萠出永久菌のDMFT 指数の抑制率について

結果は Table 20に示したが，全永久歯については新 萌出歯の方に高い抑制勃果があらわれている。一方第一 大鼠では，新萌出歯と既萌出歯の抑制率に，それほど の差がないようにも見受けられるが，これは新萌出菊数 が極端に少ないため明らかではない。

このうち全永久菌のみ Fig. 11に示してみたが，既萌 出画・新萌出歯ともに，抑制率は経駼年数の增加にとも ない上䄯しており，両者の差はむしろ䈹少している。こ れは次のように考えられるのではなかろらか。それは初 年度の口腔内診查時にう触として検出されなかった病理 
Table 18 The year-course of DMFT index in previously erupted teeth

\begin{tabular}{|c|c|c|c|c|c|c|c|}
\hline \multirow[b]{2}{*}{ school } & \multirow[b]{2}{*}{ teeth } & \multicolumn{6}{|c|}{ participation period (years) } \\
\hline & & 1 & 2 & 3 & 4 & 5 & 6 \\
\hline \multirow[b]{2}{*}{$\begin{array}{l}\text { A (fluoride } \\
\text { group) }\end{array}$} & al1 teeth & 0.51 & 0.58 & 0.91 & 0.81 & 0.84 & 0.95 \\
\hline & $1 \mathrm{st}$ molar & $\begin{array}{l}0.51 \\
(100)^{*}\end{array}$ & $\begin{array}{l}0.57 \\
(97.8)\end{array}$ & $\begin{array}{l}0.91 \\
(100)\end{array}$ & $\begin{array}{l}0.81 \\
(100)\end{array}$ & $\begin{array}{l}0.84 \\
(100)\end{array}$ & $\begin{array}{l}0.94 \\
(98.7)\end{array}$ \\
\hline \multirow[b]{2}{*}{$\begin{aligned} & B(\text { control } \\
&\text { group })\end{aligned}$} & all teeth & 0.68 & 0.86 & 1.21 & 1.48 & 1.46 & 1.76 \\
\hline & lst molar & $\begin{array}{l}0.68 \\
(100)^{\star}\end{array}$ & $\begin{array}{l}0.70 \\
(81.5)\end{array}$ & $\begin{array}{l}0.98 \\
(81.6)\end{array}$ & $\begin{array}{l}1.25 \\
(84.9)\end{array}$ & $\begin{array}{l}1.10 \\
(75.0)\end{array}$ & $\begin{array}{l}1.38 \\
(78.4)\end{array}$ \\
\hline
\end{tabular}

* Numbers in parentheses show percentages of DMFT of first molars against the total of all teeth.

Table 19 The year-course of DMFT index in newly erupted teeth

\begin{tabular}{|c|c|c|c|c|c|c|c|}
\hline \multirow{2}{*}{ school } & \multirow{2}{*}{ teeth } & \multicolumn{6}{|c|}{ participation period (years) } \\
\hline & & 1 & 2 & 3 & 4 & 5 & 6 \\
\hline & al1 teeth & 0.05 & 0.24 & 0.46 & 0.43 & 0.60 & 1.13 \\
\hline $\begin{array}{l}\text { A (fluoride } \\
\text { group) }\end{array}$ & $1 \mathrm{st}$ molar & $\begin{array}{l}0.05 \\
(100)^{*}\end{array}$ & $\begin{array}{l}0.20 \\
(83.3)\end{array}$ & $\begin{array}{l}0.32 \\
(69.6)\end{array}$ & $\begin{array}{l}0.29 \\
(67.4)\end{array}$ & $\begin{array}{l}0.32 \\
(53.3)\end{array}$ & $\begin{array}{l}0.42 \\
(37.2)\end{array}$ \\
\hline & a11 teeth & 0.08 & 0.27 & 0.68 & 1.11 & 1.08 & 2.37 \\
\hline $\begin{array}{l}\text { B (control } \\
\text { group) }\end{array}$ & 1st molar & $\begin{array}{c}0.05 \\
(62.5) \text { * }\end{array}$ & $\begin{array}{l}0.17 \\
(63.0)\end{array}$ & $\begin{array}{l}0.32 \\
(47.1)\end{array}$ & $\begin{array}{l}0.56 \\
(50.5)\end{array}$ & $\begin{array}{l}0.41 \\
(38.0)\end{array}$ & $\begin{array}{l}0.65 \\
(27.4)\end{array}$ \\
\hline
\end{tabular}

* Numbers in parentheses show percentages of DMFT of first molars against the total of all teeth.

Table 20 The year-course of caries reduction rate (\%) expressed with DMFT index in previously or newly erupted teeth

\begin{tabular}{l|l|c|c|c|c|c|c}
\hline \multirow{2}{*}{ teeth } & \multirow{2}{*}{ eruption } & \multicolumn{5}{|c}{ participation period (years) } \\
\cline { 3 - 8 } & & 1 & 2 & 3 & 4 & 5 & 6 \\
\hline \multirow{3}{*}{ al1 teeth } & previously & 25.0 & 32.6 & 24.8 & 45.3 & 42.5 & 46.0 \\
\cline { 2 - 8 } & newly & 37.5 & 25.9 & 32.4 & 61.3 & 44.4 & 52.3 \\
\hline \multirow{2}{*}{1 st molar } & previously & 25.0 & 18.6 & 7.1 & 35.2 & 23.6 & 31.9 \\
\cline { 2 - 8 } & newly* & 0 & -17.6 & 0 & 48.2 & 22.0 & 35.4 \\
\hline
\end{tabular}

* not clear because of the small numbers of teeth. 
Table 21 The year-course of the correlations between the number of permanent teeth at the start of the experiment and DMFT index

\begin{tabular}{c|c|c}
\hline participation period (year) & school A (f1uoride group) & school B (control group) \\
\hline 0 & $r=0.602$ & 0.442 \\
1 & 0.647 & 0.488 \\
2 & 0.491 & 0.451 \\
3 & 0.500 & 0.482 \\
4 & 0.400 & 0.414 \\
6 & 0.443 & 0.396
\end{tabular}

$(p<0.01$ in a11)

Table 22 The year-course of the correlations between the number of permanent teeth after one year of the experiment and DMFT index

\begin{tabular}{c|c|c}
\hline participation period (year) & school A (fluoride group) & school B (control group) \\
\hline 1 & $\mathrm{r}=0.491^{*}$ & $\mathrm{r}=0.383^{*}$ \\
3 & $0.392^{*}$ & 0.328 \\
4 & $0.425^{*}$ & $0.397^{*}$ \\
5 & 0.325 & $0.380^{\star}$ \\
6 & $0.370^{*}$ & $0.471^{\star}$
\end{tabular}

$\star p<0.01$

学的う強が相当数存在し，1年後，つまり程駼年数 1 年 次に，F洗口により抑制できずに，臨床的う触にまで進 行してしまったものがかなりある。そのため初めの既萌 出歯の抑制率は $25 \%$ と低くなっている。一方その他の病 理学的う蝕はFの曝露により, 再石灰化が促進されたり する結果 ${ }^{48-48)}$ ，臨床的う触にまで進行せずに，抑制率の 上梨という形であらわれたものと考えるわけである。

11. 永久蔽の萌出亩数と DMFT 指数について

永久歯の萌出時期にはかなりの個体差があることが知 られているが, 今回の調查においても，経験年数 0 年次 の萌出永久歯数には，0〜12画のばらつきがみられた。
このうち萌出永久踩数の多い児童は, 萌出時期が早いも のと考えられ，う蝕原性の刺激を早期から受けることに なり，萌出時期の遅い児童よりう蝕発生の危険が大きい ものといえる。

そこで，このような現象に対するF洗口の効果を検郡 する意味で，次のような調查を行った。すでに两校間の 永久歯萌出状態に差のないことがわかっているため, 経 験年数 $0 \cdot 1$ 年次の萌出永久歯数と, その後のう蝕増加 との相関を調べた。結果は Table $21 ・ 22 に$ 示したが, やはり萠出齔数の多い児童ほどう強の発生も早いようで ある。しかしA小学校の相関は, 経験年数の増加にとも 
Table 23 Correlations between DI-S value and DMFT index

\begin{tabular}{c|c|c}
\hline school & r. & significancy \\
\hline A (fluoride group) & 0.07 & N.S. \\
\hline B (control group) & 0.30 & $\mathrm{p}<0.01$ \\
\hline
\end{tabular}

Table 24 Relation between the fluoride concentration in rinsing solution and the products on the surface enamel

\begin{tabular}{c|c}
\hline fluoride concentration (ppm) & products \\
\hline$<100$ & F-hydroxyapatite \\
$\qquad 100$ & F-hydroxyapatite \\
$<2,000$ & CaF $_{2}$ \\
\hline
\end{tabular}

(adapted from B. Forsman'29)

ない弱まり, Table 22の経験年数 6 年次では有意性がな くなるほどである。これに対しB小学校では，逆に强ま る傾向を見せており，これが通常の関係であると思われ る。A小学校においてみられた相関の娍弱は, とりもな おさずF洗口の抑制効果によるものである。

\section{2. 首口赫状管（DI-S 值）と DMFT 指数につい} $\tau$

歯みがきに関する齿科保健生活行動調查結果と, 経験 年数 6 年次の DMFT 指数に関連性がみられなかった ことは既に述へたとおりであるが，ここでは，実際のプ ラーク付着状態（DI-S 值）と6 年次の DMFT 指数と の相関について調へてみた。方法は計 6 回の口腔内診査 時の DI-S 值の平均と, 経験年数 6 年次の DMFT 指 数の相関を調べることにした。

現代の概念として，「う蚛はプラークの直下から起こ る」とされている(7)ように，う強発生とプラークとの関 係が重要視されている。ところが, Table 23をみてもわ かるように， B小学校では有意な 相関が 示されている が，F洗口を実施しているA小学校では両者の関連がみ られていない。これは非常に興味深い所見であり，今回 のような条件で F 洗口を行っている場合，ある程度のプ ラーク付着量は，う蝕発生に直接的な影翼を及ぼさない とも解积できる。

\section{考察ならびにまとめ}

フッ化物の局所応用は, operator-applied（専門家応 用）と self-applied（自己応用；自律応用）とに分けら
れ15)，F洗口は後者にあたり，歯科医師または医阨など の専門家の指示のもとに, 自律的に応用する方法として 位圈つけられている。また Ericsson(3)により，唾液の 存在下においてもエナメル質にFがとり込まれることが 示されて以来, 公衆衛生特性に劣る齒面塗布法にかわる ものとして，大きな進展をみせたのである。

しかしながら，洗口液のF湛度は45 3,000ppm, 洗 口の頻度は年 3 ・4 回から1 日 2 回までとかなりの開き がある。この中でも, 大きく分ければ, 低㴗度高頻度洗 ロプログラムと高簧度低頻度洗ロプログラムの 2 つに分 類でき，前者は効果が高くより安全であるため家庭応用 に，後者は効果がやや劣るものの集団応用の場合の受け 入れ易さから，学校単位の応用として推奖されてい る $^{12,15)}$ 。

また踩の萌出以前，つまり永久歯に関しては $4 \cdot 5$ 歳 児から洗口を開始した方が，より高い効果が得られると いう報告 ${ }^{13,26)}$ がある。F洗口に関する安全性は, 洗口後 の口腔内残留量からも検討され29,48-52)，十分に確立され たものではあるが，湽料水にF添加の行われている地域 などでは，4・5歳児という低年战児の F 洗口に対して は危惧の念をいだく報告 ${ }^{15,58,54)}$ も少なくない。これは挍 取 F 量が過剩になり過ぎるため，4・5 歳児頃形成され る永久齿に歯牙フッ素症が発現する恐れがあるとしたも のであるが，0.025\% NaF 溶液のように低湌度の洗口 液の場合, その心配はないという29)。

このような現状の中で，Fとして100ppmという，従 来あまりみられない低浱度洗口液を用いた週 5 回の洗口 
を，A小学校に対して 6 年間継続実施したところ，B小 学校に比へ有意なう蝕抑制効果を虫めた。DMF 指数の 抑制率は，所有者事で $25.2 \%$, 歯数で $52.2 \%$ ，歯面数で $51.0 \%$ あり，他の F 洗口の効果4-29)に比較しても，決 して逊色のないものであると思われる。このように，低 㵲度フッ化物溶液による洗口は, 学校蔽科保侓管理上,

極めて有効であることから，実施施設の受け入れ体制の 如何により，4・5墄児からの実施をも推奖できるもの である。

以下今回の調査によって得られた情報を整理するとと もに，若干の考察を加えてみたい。

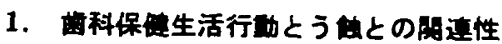

今回の調査では, 僄陪の両者に密接な関係を見い出す ことはできなかった。その中でも, 間食とう触との間に は，わずかながら関連があるようであったが，齿みがき については全くといってよいほど開連がみられなかっ た。そこで，う強発生の直接の原因上なるプラークをと り上げ，その付着状瑟々う強との関連について検討し た。その結果， B小学校（非洗口校）のみ有意な相関か： 得られ，A小学校（F洗口校）には相関が認められなか ったのである。このあたりが低湌度 $\mathrm{F}$ 洗口の作用機序の 1つの鍵となっていることが考えられる。つまり，唾液 (洗口液)ープラークーエナメル質表層」という関係での Fの相互作用ということであるが，この点に関しては， さらに実呤的な研究が必要である。

\section{DMFT 指数におけるう抑制効果について}

今回の調查は, 同一地域内に存在する各種要因の類似 した 2 小学校を対象に，F洗口以外は全く同梯な歯科保 健管理を実施したものであり，小学校入学時点から卒業 時点までのおよそ 6 年間, 永久齿う蝕発生状況を追跡調 查することにより，う蝕抑制協果を判定したものであ る。A小学校を洗口校，B小学校を対照校とした最終時 点での DMFT 指数のう蝕抑制効果は，およそ50\%と 有意な差であったが，小䈉溰う蝕に対してはやや低い ようであった。しかしながら、この小笠清う䖵のほと んどは第一大臼齿で占められていることから, 萌出以前, つまり $4 \cdot 5$ 歳児から洗口を開始した場合の抑制効果に ついて検討しなければ, 明らかな結論は出せないところ である。さらに第二大臼齿を初めとする萌出時期の遅い 菌種に対しては，そのう触発病時期のピークを考虑する と, 中学校 3 年生頃に㧕制効果を判定する必要があるも のと思われた。

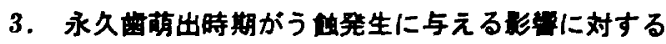
$\mathrm{F}$ 洗口の抑制奻果
小学生における年龄の增加と永久歯のう䖵增加との間 には，直線的な関係のあることが知られている27)。これ はFig. 3でも示したように，年龄と永久歯の萠出菌数 との閪に直線的な関係があり，各歯が段階的にう䖵発病 時期を迎えるからである。しかしながら，永久歯の萠出 時期にはかなりの個体差があり, 萌出時期の早い者ほど う触発生が早期（年龄的に）になる危険性が大きい。と ころが，A小学校においては，F洗口を実施することに より、このような自然の関係が阻害されるという好影慗 がもたらされた。さらにその関係が，程験年数の增加上 ともに弱められているのは, 学童期にう䖵発病時期のピ

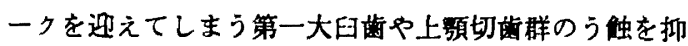
制できたからにほかならぬものと思われる。

このう䖵発病時期を晕延させるという効果が, 終生の う蝕抵抗性を獾得したことによるものなのか，またF洗 口を継続している間のみ発揮されるものなのか, 複雑な 作用機序を解明する釆口としても，今後検討しなければ ならない重要な課題であろう。

4. Fとして100 ppm という裂度について

本研究において100ppm という源度を設定した根拠 は，次の如くである。Forsman'29)が述べている，洗口液 中のF蹗度とアパタイト結晶中に局所的に生成される物 啠との関係は，Table 24のようにまとめることができ る。最終的にう触抵抗性を獾得するためには，F-hydroxyapatite の存在が重要な意義を持つ55 ことから，100 ppm という滥度設定を行ったわけである（実際に洗口 に使用すれば，唾液で希釈されて，これよりやや低い䈨 度となる)。これより低灌度であっても，例えば $1 \mathrm{ppm}$ でもう触抑制効果が発揮されるという報告15,56,57)もある が, 歯牙形成期中に人工的な $\mathrm{F}$ 璂露のない地域にとっ て，また口腔内では唾浓により希釈されること，さらに 1 日1回，しかも30秒閏という短時間の F 局所曝落であ ることを考え合わせれば、このあたりが十分なう触抑制 効果の発現する最小湌度ではなからうかと考えたわけで ある。

以上, Fとして100ppm という低溇度のフッ化物溶液 によるう蝕抑制劣果について検討したところ，十分なう 触抑制効果を発揮することが明らかとなった。今後検討 すべき点は多々あるが，学校齒科保健プログラムにおけ る，有効かつ適切な手段として推奖できるものと思われ た。

稿を終るに際し，絶えす御指導，御校閲を下された饭 塚亮一数授に深即するとともに，絶えさる御援助をいた だいた，矢崎武先生をはじめとする元教空員ならびに現 
教室員諸氏に深く御礼申し上げます。さらに本研究に協

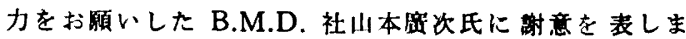
す。

な㧍，本研究の一部は，「文部省」科学研究贾補助金 および「富徳会」研究助成金によったものであることを 記し，磾意に代えさせていただきます。

\section{文献}

1）日本齿科医師会訳：FDI一世界各国の歯科医業 に関与る基本事項調查, 日本歯科医師会湖查室, 東京, 1977.

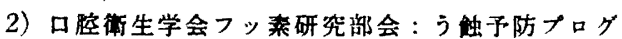
ラムのためのフッ化物応用に対ナる見解，口衛 誌, $32 ; 421-430,1982$.

3) Silverstein, S. J., Wycoff, S. J. and Newbrun, E. : Sociological, economical and legal aspects of fluoridation; from "Fluorides and Dental Caries-Contemporary concepts for practitioners and students", 2 nd Ed., Chap. 4 (ed. Newbrun, E.). Charles C. Thomas, Springfield, IIl., 1975, pp. 81-98.

4) Bibby, B. G., Zander, H. A., Mckelleget, M. and Labunsky, B.: Preliminary reports on the effect on dental caries of the use of sodium fluoride in a prophylactic cleaning mixture and in a mouthwash ${ }^{1}, \mathrm{~J}$. Dent. Res., 25 ; 207-211, 1946.

5) Weisz, W. S. : The reduction of dental caries through use of a sodium fluoride mouthwash, J. A. D. A., 60 ; 438-457, 1960.

6) Torell, P. and Ericsson, Y.: Two-year clinical tests with different methods of local caries-preventive fluorine application in Swedish school-children, Acta Odont. Scand., 23 ; 287-322, 1965.

7) Torell, P. and Ericsson, Y.: The value in caries prevention of methods for applying fluorides topically to the teeth, Int. Dent. J., 17 ; 564-581, 1967.

8) Swerdloff, G. and Shannon, I. L. : Feasibility of the use of stannous fluoride mouthwash in a school system, ASDC J. Dent. child., 36 ; 363-368, 1969.

9) Birkeland, J. M. and Torell, P.: Cariespreventive fluoride mouthrinses, Caries Res., 12 (Suppl. 1) ; 38-51, 1978.

10) Horowitz, H. S, Heifets, S. B., Mayers, R. J., Driscoll, W. S. and Shou-Hua, Li : A program of self-administered fluorides in a rural school system, Community Dent. Oral Epidemiol., 8 ; 177-183, 1980.

11) Hausen, H., Heinonen, O. P. and Paunio, I. : Fluoride exposure combinations and ca- ries in permanent dentition among Finnish children, Community Dent. Oral Epidemiol., 9 ; 108-111, 1981.

12) Ripa, L. W.: Fluoride rinsing: What dentists should know, J. A. D. A., 102 ; 477-496, 1981.

13) Ripa, L. W., Leske, G. S., Sposato, A. L. and Rebich, Theodore, Jr. : Supervised weekly rising with a $0.2 \%$ neutral $\mathrm{NaF}$ solution: results of a demonstration program after four school years, J. A. D. A., 102 ; 482-486, 1981.

14) Poulsen, S., Gadegaard, E. and Mortensen, B. : Cariostatic effects of daily use of a fluoride-containing lozenge compared to fortnightly rinses with $0.2 \%$ sodium fluoride, Caries Res., 15 ; 236-242, 1981.

15) Horowitz, H. S. : Alternative methods of delivering fluorides: un update, dental hygiene, $57 ; 37-43,1983$.

16）可児瑞夫：フッ秦含有洗口都化よる触予防 法，齿科時報，24:12-16，1970。

17）可児瑞夫，藤岡三之烳，長领陽子，笛士公子， 可児徳子, 松村敏治：フッ素含有洗口液に上る 洗口法のう能挷制効果について，口街芯，23； $68-74,1973$.

18）可児瑞夫：䖵子防のためのフッ化物洗口法, 口衛誌，27；41-57，1977.

19）可児瑞夫：フッ化物洗口法の位置うけ，界儌 望, $50 ; 1033-1045,1977$.

20）可児瑞夫，可児徳子，嘰绮篤則，山村利貞，中 西国夫, 大西重内, 鸆木 達, 岩崎 宏, 饭野 新太郎, 高棉美㰠：小学校に㧍けるフッ化物応 用に上るう蝕予防効果について，歧鼻歯科学会 䧴䓌，6；24 28，1978.

21）境份，小佐 8 順夫，蓡内影史，越 澄美， 白石敏彦, 珮井欣一：小学学童に求けるフッ秦 含法によるう能予防一3年間の経過做察デー 夕による解析一， 口御誌，23；128-129，1973.

22）笠合てる子：学校給食汇関士る考学的考察，第 3 編，学校給食時における弗化ナトリウム溶液

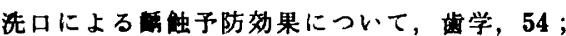
$22-32,1966$

23）帛田弘, 管沢光正, 岛田哲男：2小学校にお ける弗化ンーダ洗口実嗝, みちのく齿学会雑誌, $4 ; 9-17,1973$.

24）島田義弘，岛田哲男：弗化ソーダの洗口頻度を 月 1 回から週 1 回に変更して得られた触抑制 奻果, みちのく歯学会雑范, $6 ; 1 \sim 5,1975$.

25）岛田義弘, 高木興氏, 井上博之：低湜度フッ化 ソーダ没洗口による触城少奻果にっいて，口 衛䓽, $28 ; 1-9,1978$.

26）小林清吾, 简井昭仁, 小佐々順夫, 境俏, 城井欣一：一地域学童におけるフッ素洗口法に 上る永久齿う䖵予防効果, 新渴齿学会䓌, $8 ; 1$ 
$-9,1978$.

27) 木炊英五：小，中学生永久歯う蝕の策団管理， 口衛誌, 28 ; 148-169，1978.

28）筒井昭仁，田村卓也，萳藤慎一，境偷，堀 井欣一：学咅におけるフッ来洗口法によるう蝕 予防効果一群間および群内比較による解析一, 口街誌, 28 ; 340, 1978.

29) Forsman, B.: The caries preventing effect of mouthrinsing with $0.025 \%$ sodium fluoride solution in Swedish children, Community Dent. Oral Epidemiol., 2; 58-65, 1974.

30）安彦良一, 原 康二, 石田觉也, 荒川浩久, 浅 井康年，平田幸夫，久保田昌子，菅原但子，饭 塚豆一：口陡内写真を用いた新しい齿科健康管 理活動, クインテッセンス・ジャーナル, 5 $(4,5) ; 57-63,71 \sim 77,1981$.

31）日本薬学会縁: 街生試殹法注解, 金原出版, 東 京, 1973, pp. 727-728.

32）口腔衙生学会上水道弗秦化委只会：上水道弗秦

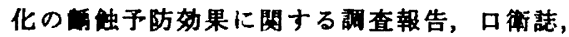
$12 ; 27-41,1962$.

33）岛田義弘：初期う蚛の検出法, 歯界展望, 29 ; 1321-1329, 1967.

34) Schröder, U., Lindström, L. G. and Olsson, L. : Interview or questionnaire ? A comparison based on the relationship between caries and dietary habits in preschoolchildren, Community Dent. Oral Epidemiol., 9 ; $79-$ 82, 1981.

35) Honkala, E., Eskola, A., Rimpela, M. and Rajala, M.: Consumption of sweet foods among adolescents in Finland, Community Dent. Oral Epidemiol. 10 : 103-110, 1982.

36) Rugg-Gunn, A. J., Holloway, P. J. and Davies, T. G. : Caries prevention by daily fluoride mouthrinsing, $\mathrm{Br}$. Dent. J., 135 ; 353-360, 1973.

37) Ashley, F. P., Mainwaring, P. J., Emslie, R. D. and Naylor, M. N. : Clinical testing of a mouthrinse and a dentifrice containing fluoride, A Two-year supervised study in school children, Br. Dent. J., 143 ; 333-338, 1977.

38）厚生省医務局齿科街生課緍：昭和56年度齿科疾 患実態調查報告，口腔保健㙝会，東京，1983， pp. 89-123.

39）杤原義人，大閔英明，野村正美，西田煡吉，岩 本一人, 宮坂太郎, 松田妥人, 川上豆久雄, 伊 藤武疄：小学校における 6 歳白齿以外の永久歯 う触について，口衛誌，17；15-19，1967.

40）竹内良伯, 加藤孝一, 岡田治夫, 赤川二郎, 矢 岛正美, 三橋刚一, 高安 昭, 黒田和资, 高㛢 陸雄: 学童集団の齿牙健康状隹判定のための第 一大臼落検訩の意義に関する研究，口衛誌，28; 531-535, 1979.
41) Going, R. E., Haugh, L. D., Grainger, D. A. and Conti, A. J.: Four-year clinical evaluation of a pit and fissure sealant, J. A. D. A., 95 ; 972-981, 1977.

42) Horowitz, H. S., Heifetz, S. B. and Poulsen, S. : Retention and effectivenss of a single application of an adhesive sealant in preventing occlusal caries: final report after five years of a study in kalispell, Montana, J. A. D. A., $95 ; 1133-1139,1977$.

43) Fehr, F. R. von der, Löe, H. and Theilade, E. : Experimental Caries in $\mathrm{Man}^{1}$, Caries Res., 4 ; 131-148, 1970.

44) Silverstone, L. M. : Remineralization phenomena, Caries Res., 11 (Suppl. 1) ; 59-84, 1977.

45) Zahradnik, R. T. : Effect of fluoride rinses upon in vitro enamel remineralization, J. Dent. Res., 59 ; 1065-1066, 1980.

46) Koulourides, T. and Cameron, B. : Enamel remineralization as a factor in the pathogenesis of dental caries, J. Oral Path., 9 ; 255-269, 1980.

47）饭塚喜一：はじめに一䖵病因論の現代の概念 一，苗界展望別冊 : 7-13，1982.

48) Ericsson, Y.: The distribution and reactions of fluoride ions in enamel-saliva environment, investigated with the radioactive fluorine isotope F18, Acta Odont. scand., 16 ; 127-141, 1958.

49）小林清吾, 大沢汐子, 筒井昭仁, 榎田中外, 境 修，墹井欣一：低年令児におけるフッ素洗口時 の口腔内フッ素残留量について, 新渴齿学会誌, $7 ; 13-19,1977$.

50）可児瑞夫, 可児徳子, 富松早苗, 新海研志, 山 村利貞：フッ化物洗口法に伴う洗口液中フッ秦 の口腔内残留是について， 口街誌，26；281285, 1977.

51) Parkins, F. M. : Retention of fluoride with chewable tablets and a mouthrinse, J. Dent. Res., 51 ; 1346-1349, 1972.

52) Wei, S. H. and Kanellis, M. J. : Fluoride retention after sodium fluoride mouthrinsing by preschool children, J. A. D. A., 106 ; 626-629, 1983.

53) Ericsson, Y. and Forsman, B. : Fluoride retained from mouthrinses and dentifrices in preschool children, Caries Res., 3 ; 290-299, 1969.

54) Kanellis, M., Wei, S. H. Y., Krell, D., Warren, W. C. and Louie, R. : Fluoride retention following mouthrinsing by preschool children, J. Dent. Res. IADR Abstract \#920, 61 ; 281, 1982.

55）趾塚咅一：口腔衛生学, 永末書店, 京都, 1972, 
pp. 256-264.

56) Hayes, R. L., Littleton, N. W. and White C. L. : Posteruptive effects of fluoridation on first permanent molars of chidren in $\mathrm{Gr}$ and Rapids, Michigan, Am. J. Pub. Health,
47 ; 192-199, 1957.

57) Becker Dirks, O.: The assessment of fluoridation as a preventive measure in relation to dental caries ${ }^{1}, \mathrm{Br}$. Dent. J., $114 ; 211-$ 216, 1963.

\begin{abstract}
Supervised daily mouth-rinsing with a $0.023 \%$ weakly acid (pH: 5.0) NaF solution (100 ppm F) : (I). Results after six school years. Hirohisa ARAKAWA* .Fluoride mouth-rinsing programme is widely spreading over districts where the fluoride concentration in the drinking water is low or the fluoridation of communal water can not be realized, as a relatively easy and effective method of inhibiting dental caries. The most commonly used fluoride mouth-rinsing solution for daily use is a neutral $0.05 \% \mathrm{NaF}$ solution (225ppm $\mathrm{F}$ ). The rationale for this concentration, however, is not so clear. It is necessary, therefore, to investigate whether a weaker fluoride solution would have sufficient cariostatic effect. If it does, we could select the weaker solution and practice caries prevention with more safety.
\end{abstract}

The present study was carried out in two elementary schools in the same district. The experimental group (school A) rinsed daily with a weakly acid ( $\mathrm{pH}$ 5.0) sodium fluoride solution (100ppm F) at school under supervision and was given a routine school-based dental health administration. On the one hand, the control group (school B) was given the same dental health administration but without fluoride mouth-rinsing. The children of school $\mathrm{A}$ were instructed to rinse with $10 \mathrm{ml}$ of solution every school-day except Saturday, following the tooth brushing after lunch. Rinsing supervised by teachers was performed for 30 seconds (about 200 times per year). The dental examination was performed by trained dentists under standardized conditions as to light, mirrors, and explorers. The effects of rinsing were determined prospectively by comparing the dental caries experience of the children who had continuously participated in this study from the lst to the 6 th grade, 79 children in school $\mathrm{A}$ and 63 children in school B.

The results of rinsing with the weaker solution showed significant inhibition of dental caries. After 6 years, the caries reduction in children of school $\mathrm{A}$ was about $50 \%$ in the mean DMFT, which was statistically significant $(p<0.001)$. It was also observed that the fluoride mouth-rinsing confers superior benefits to smooth surfaces than to surfaces having pits and fissures, as previously reported. The cariostatic effect on the first molars was not so great as on other teeth.

To provide greater topical benefits for permanent teeth, therefore, it is necessary to start rinsing as early as possible. It may be considered that the age of 4 or 5 years is the time of choice in the beginning of rinsing. The results of this study suggest that fluoride mouth-rinsing with a weaker $\mathrm{NaF}$ solution is a practical and suitable method for school-based programs because of its efficacy and safety.

Koy words: mouth rinsing, weaker fluoride solution, caries prevention. 